Nicholai Studies, Vol. I, No. 2 (2021): 249-266.

DOI: https://doi.org/10.46825/nicholaistudies/ns.2021.1.2.249-266

\title{
Nicholai Velimirovich:
}

\section{The Great War and America 1915-1918}

Irinej Dobrijevic

Bishop of Eastern America

The Serbian Orthodox Church, New York

diocese@easterndiocese.org

Abstract: The unique and broadly encompassing embrace of Nicholai Velimirovich, an inspired, charismatic and erudite individual, is difficult to succinctly present within the limitations of a single essay. Therefore, his religious and socio-political witness to America, concerning the plight of the Serbs during The Great War, as well as the response of his American contemporaries, institutions and media to him the person and to his message, shall be the focal point of this presentation. Nicholai's distinct mission to America in 1915 must be understood in its proper historic context, as aspects of the same do remain as relevant today, as they were in their day.

Key words: The Great War, Nicholai Velimirovich, America.

\section{Introduction}

His academic background is scholarly and distinguished. He was a prolific writer and an eloquent orator; an inspired theologian and poet; a prophet and a visionary; a mystic and an apologist; an effective pastor and intellectual; as well as a skilled diplomat and Christian statesman. He was, without a doubt,

"The previous version of this paper was published in Vidakovic Petrov 2018, 229-237 (see bibliography bellow). 
the harmonious embodiment of faith and culture, Christianity and patriotism. The testimony of this extraordinary person has been the subject of voluminous and often, conflicting writings. In the Serbian Orthodox Church, he is regarded as the "New Chrysostom" and, to his American contemporaries, he was known as a "Second Isaiah."

Nicholai's collective works have been assembled into an encyclopedic set of volumes, spanning the various languages and traditions he had come to master. Nicholai was fluent in seven languages. His works always evoke the eternal and never the temporary. Each work is universal, including within itself various and diverse elements and covering numerous aspects and concerns. Nicholai was himself the patristic embodiment of an Orthodox intellectual and philanthropist, freely lecturing in the halls of the world's most eminent universities, and as comfortably addressing royalty, as the simplest among his flock.

\section{An American Mission - 1915}

In the summer of 1914, with the outbreak of The Great War, subsequently known as World War I, the Balkan Peninsula was hurled into complete and utter turmoil. The Serbian nation was in dire need of a charismatic leader to help them bridge this international crisis. For this purpose, the young hieromonk, Dr. Nicholai Velimirovich, professor at the Theological Faculty of the University in Belgrade, was commissioned by the Royal Government of the Kingdom of Serbia, on an official diplomatic mission to Great Britain and the United States, to foster awareness and recruit support for the suffering Serbian people. He was received everywhere with full honor and dignity. Nicholai effectively displayed his keen political astuteness, not only in addressing the issue of the Serbs, but also by directing his attention to the cause of world peace and methodologies given unto political ideals. At his influence, the British Parliament voted to accept the emerging South Slav state into the League of Nations. 
By the second half of June in $1915,{ }^{1}$ Nicholai Velimirovich arrived in America, together with Dr. Dushan Grgin; Mr. Raka Majstorovich, a chemical plant director; Lt. Col. Jevrem Popovich from Kragujevac, who, as noted, was missing one hand; and 18 other young men, who were to review various materials and receive military supplies (Vukovic 1990, 89-90). However, Nicholai's express purpose was to gather the émigré Serbs, Croats and Slovenes in solidarity, given their common plight in the Austro-Hungarian Empire, from which many had fled to America. Simultaneously, Metropolitan Dimitrije of Belgrade charged Nicholai with visiting Serbian parishes throughout Northern America. Permission was secured for the same from Archbishop Eudokim of the Aleutian Islands and North America, being that the Serbian parishes were under the jurisdiction of the Russian Orthodox Mission of North America.

\section{Publications}

A man of letters, immediately upon their arrival, Nicholai published in the "Serbian Daily" an article titled, "200,000 Serbs perished for Freedom". Among all else, he noted "That self-defense must have been a necessity for the cost was expensive. Serbian justice must have been great, both human and Divine, for the cost was expensive. Serbia is stronger and fresher than ever." As such Nicholai quickly embarked on a lecture tour in order to familiarize Americans with the suffering of the Serbian people in their struggles for freedom (Vukovic 1990, 90).

As part of his pan-Slavic endeavors, he published two articles in Living Church: The Weekly Herald of Slavic Christianity, titled, "The Highest" and "Moses". In "The Highest", he notes that he has come to this world, where "work is prayer to God; where work is poetry; where work is life. 'Work as long as you

\footnotetext{
${ }^{1}$ According to Milkic 2016, 95, Nicholai was in the United States from April, 1915 to autumn, 1915. Nicholai was, however, in London from April to June, 1915 and then again from autumn, 1915 to April, 1919.
} 
have light!' America has completely fulfilled this commandment of the Teacher." (Velimirovich 1915, 3).

\section{Philanthropic Endeavors}

Nicholai Velimirovich, thereafter, became an instrumental member of the "Serbian Relief Committee", headquartered at 7o Fifth Avenue in New York and organized by honorary Serbian Consul General to the United States, Professor Dr. Michael Idvorsky Pupin of Columbia University, and recently-elected President of the Central Committee of the Serbian National Defense (cf. Zivojinovic 1984, 49). Independently, and as a member of the "Serbian Relief Committee", Nicholai solicited desperately need funds, which, cumulatively, according to some historians, amounted to 140 million dollars in order to assist the suffering population of Serbia. ${ }^{2}$

On July $1^{\text {st }}$, Nicholai met with Mrs. Helen Losanitch-Frothingham, the appointed Serbian Red Cross delegate to America, also a member of the "Serbian Relief Committee", who was soliciting funds throughout America and Canada for both entities. At the time, she was visiting New York City and staying at the Women's University Club. Her reputation as a philanthropist was such that she even managed to enlist in her committee, those dismissed by New Yorkers, as the nouveau riche of Chicago, such as Mrs. McCormick and others, whom she deemed, "most helpful, courteous, generous and kind" (Frothingham 1970, ix and 24).

In her book, Mission for Serbia: Letters from America and Canada 1915-1920, Helen notes how she had been expecting Fr. Nicholai and that they spoke for nearly three hours. She found him to be deeply spiritual and quite knowledgeable of life and human beings. He conveyed the distressing news from Serbia, the "terrible mortality from typhus and the acute problem of

2 This figure is noted in Grcic and Gnjato 2004, 75. 
the uncared for orphans". The conversation continued as he conveyed, personally from his own family, "four of my relatives have already died in Machva, and eight have perished from typhus". He urged her to continue her work, as there was so much more to be done (Frothingham 1970, 25).

Reflecting in her book, Mission for Serbia: Letters from America and Canada 1915-1920, published in 1970, she describes Nicholai, as "one of the most outstanding personalities of the Serbian Orthodox Church of modern times. He was a philosopher, theologian, writer, poet, and eloquent preacher. During World War I he became well known in England and the United States for his sermons delivered in the Anglican and Episcopal churches" (Frothingham 1970, 25).

Her work was quite selfless and truly noteworthy. Helen, who arrived in her early twenties, travelled for her cause from early 1915 to 1921, often alone, under conditions that are now unimaginable. She was able to garner introductions to women of great standing and solicit the likes of Mrs. John Henry Hammond, Mrs. Colgate Hoyt, and Mrs. J. P. Morgan. She refers to Mr. Murry Coggeshall, a very successful banker in New York, as a great asset, "for he is widely known for his integrity and great financial ability". They spoke for well over two hours with regard to the situation in Serbia. As a reputable business man of such standing, according to her, he would not waste his time in trivial discussions. It was the tragic plight of Serbian war orphans that concerned him most, as he had tremendous sympathy for children. And the ability to help Serbia's poor children gave Helen great satisfaction and fulfillment in life (Frothingham 1970, ix, 26-27, 103, 217 and 287-288).

In light of the growing number of impoverished war orphans, by September 1915, Nicholai, together with other members of the "Serbian Relief Committee", formed the "Serbian Child Welfare Association" (Grcic and Gnjato 2004, 96) to aid the many homeless, destitute and orphaned children throughout Serbia, who were also great assisted by Helen LosanitchFrothingham. 


\section{The Anglican Communion}

According to Canon Edward N. West, former Sub-Dean of St. John the Divine Cathedral in New York, renown liturgist and heraldic authority, prior to the 1915 arrival of Hieromonk Nicholai, the Anglican Communion viewed with remoteness the "exotic Eastern Orthodox Faith". In his "Recollections of Bishop Nicholai", whom he befriended and greatly admired, ${ }^{3}$ West writes how it was Nicholai who was personally responsible for the unveiling of Orthodoxy to the various Christian denominations, particularly the Anglican Communion in Great Britain and the United States.

As such, Westminster Abbey had invited the most attractive and literate priest of Serbian Orthodoxy of his day to come to London in early 1915 and lead Englishmen in the Way of Saint Sava:

"The First World War brought a sudden and profound concern for the imperially throttled Serbs, and, as a result ... Nicholai Velimirovic[h] came, and in three months left an impression that continues to this day. His vision of the Church as God's family, as over against God's empire, simply shattered the West's notion of what it had regarded as the Caesaro-Papism of Eastern Orthodoxy."

Dr. William Manning, rector of the prestigious Trinity Church on Wall Street, subsequently, invited Nicholai to New York. The

\footnotetext{
${ }^{3}$ Canon West commissioned one of the first known icons of Bishop Nicholai, immediately following his repose in 1956, which became the standard for most latter icons.

${ }^{4}$ Cited according to 1979 Calendar of the Serbian Orthodox Church in the USA and Canada 1979, 84.
} 
end result was 'electrifying', according to Canon West. A lasting and deep personal affection developed between Drs. Manning and Velimirovich, who was to become Bishop of Zhicha in 1919. Thereby, William Manning invited him back to the United States in 1921, requesting his presence at his own consecration as Tenth Episcopal Bishop of New York (Dobrijevic 1979, 1316). The tangible fruition of this remarkable Christian friendship was evidenced in the gifting of the Trinity Chapel in New York to the Serbian Orthodox Church, later to become the St. Sava pro-Cathedral of New York, in 1943.

\section{Fiery Homilies and Rousing Lectures}

Nicholai took advantage of this initial American visit to travel extensively throughout the United States. At every major city which he visited, Nicholai delivered outstanding homilies and speeches that captivated his American audiences by oratory and presence. Having returned from a triumphal visitation to California, as a certain Mr. Rankovich noted, "he swept clean everything before him" (Vukovic 1990, 90).

Nicholai in a letter dated July $14^{\text {th }}, 1915$ to Hieromonk Aleksija Savich, Serbian parish priest in Pittsburgh, wrote, "I received the invitation for your gathering in Pittsburgh, and I will be there God-willing, on Saturday... I anticipate that you will do everything on your behalf so that your gathering will be to the pride of the Serbs and not an embarrassment". As he was concerned that various factions would vie for influence at the gathering, Nicholai requested that one of the conveners, a Mr. Vukorovich, and others, work together in harmony for the success of the proposed gathering (Vukovic 1990, 90).

Six days following, Nicholai and Rev. Savo Vojvodich, together with Messrs. Maksim Relich and Joseph Smith, summoned a gathering of South Slav clergy for August $24^{\text {th }}$ at the LaSalle Hotel in Chicago, noting in their invitation: 
"Very Reverend brother in Christ, in these fateful days for our South Slav peoples, when our brethren in Europe are fighting for the honor of the entire Slavic race and when our people in America on numerous occasions up until now have declared themselves in favor of the liberation and unification of our nations, even we South Slavic clergy must come to an agreement, as to what we at this moment can achieve in solidarity for our general national being.

As this invitation is of exclusive national importance, and that being the greatest, you are requested to come without excuse."

That same day, being August $20^{\text {th }}$, Nicholai wrote to Hieromonk Aleksija in Pittsburgh:

"Do not rebuke this invitation of mine. If it were to concern my personal life, I would not dare to engage you from Pittsburgh to Chicago. However because of our people I would like to do this.

The $24^{\text {th }}$ of this month on Tuesday (being the most convenient day for clergy) there will be a gathering here in Chicago of South Slavic clergy. You know all of the statements, which the people have given up until now at our gatherings. However the pastors of the people have kept silent. Now they must speak up. In so doing they will aid Serbia and thwart Austria. And you have always desired that.

I will endeavor in every way, so that your expenses from Pittsburgh to Chicago will be eased.

From here we will go together there.

${ }^{5}$ Cited according to Vukovic 1990, 91. 
However, come without excuse. The work is very, very important."6

There appears to be little evidence as to the outcome of this pan-Slavic gathering of clergy in Chicago, save for a notation, "the majority of the gathered Serbs, Croats and Slovenes upheld the idea of a South Slav state".7 What seems obvious here is the divide between those clergy who were in favor of South Slav unification, and those who preferred to remain with their own, such as Croatian clergy who, despite Austrian imperial annexation, either publically or secretly, held memorial services for Emperor Franz Joseph, who died on November $21^{\text {st }}$ of the following year, 1916 (Milkic 2016, 96). Along the same divide, the Serbs of Chicago who, listening to Nicholai speak, were recorded as having been emotionally roused to the point of giving him a standing ovation, noting: "For those were flaming words interwoven with the Gospel, the Way of Saint Sava and Serbian nationalism" (Dobrijevic 2007, 459).

\section{Apogee: War and Diplomacy}

On August 29 ${ }^{\text {th }}$, Professor Michael I. Pupin, chaired a historic meeting at the Amsterdam Opera House in New York City with Hieromonk Nicholai as his principal speaker. They were joined by several hundreds of South Slavs, Serbs, Croats and Slovenes, whose people were still under the flag of the Dual Monarchy. The thrust of this gathering was to evoke sympathy for the Serbian nation in view of her plight during the Great War ("Many Slavs Here Declare for Allies" 1915, 2). Among those assembled were the representatives of 29 South Slavic newspapers in America (Vukovic 1990, 90).

${ }^{6}$ Cited according to Vukovic 1990, 91.

${ }^{7}$ Bigovic, Radovan, as cited by Milkic 2016, 96. 
The meeting was opened with the playing of the Serbian and Montenegrin national anthems by Croatian Sokol String Band, which aroused great enthusiasm, as reported the following day by the New York Times. In his opening remarks, the chairman represented the war as being, to a great extent, a conflict of economic and political aspirations of the Austro-Germanic nations and the Allies. "Germany needed the Belgian coast," he stated, while "Austria needed an outlet to the Aegean. Belgium and Serbia were in the way" ("Many Slavs Here Declare for Allies" 1915, 2). Though Pupin, unlike Nicholai, was not a proponent of the creation of a South Slavic state (Milkic 2016, 96), he evoked substantial ovation when he declared that "all the southern Slavs of Austria were strongly on the side of the Allies" ("Many Slavs Here Declare for Allies" 1915, 2).

The principal speaker was Dr. Velimirovich, from the Theological Faculty of the University of Belgrade, which was closed due to the war. He spoke at great length of the justice of the Serbian aims and the misdeeds of the Austrians. He then went on to predict the possibility of uniting the Serbs, Croats and Slovenes in Austria with the present Serbia and Montenegro in a new federal kingdom. This same idea was upheld by other speakers such as Messrs. Juro Boskovich, President of the Croatian Athletic Union; Anton Tanaskovich of the Croatian paper, Hrvatski Svijet (Croatian World); and Frank Sakser. None of the speakers, however, offered practical measures toward such a union ("Many Slavs Here Declare for Allies" 1915, 2).

Regarding Nicholai and his presentation, Rankovic records the following observation: "Exceptional language, clear as crystal, rich in expressions. Arguments as heavy as a mallet, and in a certain manner, a skillful man, was Fr. Nicholai against an iron anvil." In illustrative manner, among all else, Nicholai stated:

\footnotetext{
"When Americans ask you if you Serbs, Croats and Slovenes are one people, do not say that you are. Tell them when we speak we need to have a translator. Our customs are entire-
} 
ly different. . . Do not tell them that we are one. For if you tell them that we speak the same language, they will ask you: Then why aren't you together? They will laugh at you, they will make fun of you. Hide your shame, and tell them that we do not know one another. . . My brethren from Austria, I bear greetings from Mother Serbia, a burdened martyr, who with tears washes the blood from her wounds, she is driven, deeply immersed in her concern, she thinks of you. She greets you and asks nothing from you, save only that you extend your hand in friendship and in sonship."

As it were, included in this gathering were those individuals whose patriotism was not a healthy patriotism, regardless of which side of the South Slav unification they upheld. Most certainly, this was not lost on Nicholai. A certain person, known to be a socialist, was heard by him to have said, "Priest, if your every word were to cost a cent, I would not spend as much" (Vukovic 1990, 90).

Notwithstanding, the message of the following telegram was adopted by acclamation and sent from the gathering to President Woodrow Wilson:

"The Southern Slavs-Serbs, Croatians, and Slovenes-in session at the national South Slavic meeting convened in Amsterdam Opera House this day Aug. 29, extend to Your Excellency greetings and express their fullest confidence in the political wisdom of your Government. They are ready to follow you if called upon in time of stress and foreign aggression which may aim a blow at the powers and foundations of our democratic institutions." 9

${ }^{8}$ Cited according to Vukovic 1990, 90.

${ }^{9}$ Cited according to "Many Slavs Here Declare for Allies" 1915, 2. 
Separate resolutions, which were also adopted by the meeting, a set of which was sent to the Foreign Ministers of each of the Entente Powers, declared that "all Slovenians, Croats and Serbs consider the struggle of Serbia as their struggle, and the ideal of Serbia as their ideal. We all unanimously ask from the coming peace conference-and we ask your Excellency to assist us in this-that not one foot of the South Slavic land remain under a foreign potentate."10

Another noted passage in the resolutions, read:

"We give our word today that we shall with all legal means assist the struggle of the free Slavs and their allies; that we shall work for a firmer unification among ourselves; that we shall not seek to impede with strikes these American concerns which are supplying England, France, Russia and their allies; that we shall keep away from foreign agents, either honest or dishonest, and that we shall arouse all our brethren from their servile torpor with a declaration for liberty."11

A response to the resolutions of the meeting at the Amsterdam Opera house, inevitably came at the urging of Secretary of State Lansing, ${ }^{12}$ who on July $26^{\text {th }}, 1918$ issued an appeal that on the fourth anniversary of the Austrian declaration of war against Serbia, "American people of all faiths and creeds to assemble in their places of worship on Sunday, July 28, to voice their sympa-

${ }^{10}$ Cited according to "Many Slavs Here Declare for Allies" 1915, 2.

11 Cited according to "Many Slavs Here Declare for Allies" 1915, 2.

12 According to Ostojic-Fejic 1994, 175, it seems that the honoring of Serbia, on the fourth anniversary of the Austrian declaration of war against Serbia, had been initiated by Minister L. Mihailovich (Serbian emissary). Further, predicated on declassified State Department archival material, it had been supported by M. Pupin, on behalf of "Sloga." Only, then did it catch the attention of the Assistant Secretary of State W. Phillips, who forwarded it up the channels. The text of the proclamation was composed by Alvey A. Adee. 
thy for the people of Serbia and their oppressed and dominated kindred in other lands." 13

Following suit, on July $28^{\text {th }}$, 1918 President Woodrow Wilson presented a message to the American people. ${ }^{14}$ It was read in churches throughout the country and published in virtually all major newspapers. The Serbian flag was raised at the White House and many public buildings in the nation's capital. The message read:

"To the People of the United States:

On Sunday, $28^{\text {th }}$ of this present month, will occur the fourth anniversary of the day when the gallant people of Serbia, rather than submit to the studied and ignoble exactions of a prearranged foe, were called upon by the war declaration of Austria-Hungary to defend their territory and their homes against an enemy bent on their destruction. Nobly did they respond.

So valiantly and courageously did they oppose the forces of a country ten times greater in population and resources that it was only after they had thrice driven the Austrians back and Germany and Bulgaria had come to the aid of Austria that they were compelled to retreat into Albania.

While their territory has been devastated and their homes despoiled, the spirit of the Serbian people has not been broken. Though overwhelmed by superior forces, their love of freedom remains unabated. Brutal force has left unaffected their firm determination to sacrifice everything for liberty and independence.

It is fitting that the people of the United States, dedicated to the self-evident truth that is the right of the people of all na-

${ }^{13}$ Cited according to "Appeals to Americans to Pray for Serbians" 1918, 4.

14 Declassified State Department archival material 1-8-58 of July 17, 1962. 
tions, small as well as great, to live their own lives and choose their own Government, and remembering that the principles for which Serbia has so nobly fought and suffered are those for which the United States is fighting, should on the occasion of this anniversary manifest in an appropriate manner their war sympathy with this oppressed people who have so heroically resisted the aims of the Germanic nations to master the world. At the same time, we should not forget the kindred people of the Great Slavic race - the Poles, the Czechs and Jugo-Slavs, who, now dominated and oppressed by alien races yearn for independence and national unity.

This can be done in a manner no more appropriate than in our churches. I, therefore, appeal to the people of the United States of all faiths and creeds to assemble in their several places of worship on Sunday July 28, for the purpose of giving expression to their sympathy with this subjugated people and their oppressed and dominated kindred in other lands, and to invoke the blessings of Almighty God upon them and upon the cause to which they are pledged.

The White House, July, 1918."

It is of interest that the New York Times, on that same July $28^{\text {th }}$, carried an article, titled, "Dedicate the Flag of a New Nation: Emblem of United Jugoslavia Unfurled for the First Time in Washington". It notes that on July $4^{\text {th }}, 1918$ a ceremony was held in behalf of the Serbs, Croats and Slovenes in America, wherein Serbian Minister, Dr. Lioubomir Michailovitch raised the flag as the Jugoslav National Orchestra played the Serbian anthem. He followed as principal speaker, drawing a correlation between the principles of American Independence Day and the South Slavic struggle for independence and unification ("Dedicate the Flag of a New Nation" 1918, 8). 
Hieromonk Nicholai's mission was, indeed, overwhelmingly successful. America sent over 20,00o freedom-loving Slavic volunteers, most of whom fought heroically at the Salonica Front, and later became known as "The Third Army of Bishop Nicholai" (Heppel 2003, 34). Additionally, hundreds of thousands of dollars in aid was sent to their suffering brethren in their Fatherland. As a result in 1918, the Salonika Front was breached and Serbia liberated, paving the way for the Allied Victory, thus ending World War I.

\section{Conclusion}

It may rightfully be concluded that Nicholai's mission was productive in terms of the vast amount of philanthropic aid which he solicited, the volunteers who enlisted, and the awareness that he raised for Serbia and for her bold and selfless cause. Rightfully, it has been stated, that Nicholai did more for Serbia for her plight and cause, than the whole of Serbia's then diplomatic corps put together.

In his own words, reflecting on his diplomatic mission to America during the Great War, the then Bishop of Ochrid, wrote:

"Five years ago, I was in America. I was sent then on behalf of the Serbian government, to visit the numerous South Slavic colonies in this land, so that I could explain to our people the importance of the titanic battle: which small Serbia lead against the great Austrian Empire. With their numerous resolutions the Yugoslav people at that time declared themselves in favor of Serbia and its ideals." 15

Presently, celebrating the Centennial of President Woodrow Wilson's Declaration of July $28^{\text {th }}, 1918$ regarding Serbia, his

${ }^{15}$ Cited according to Vukovic 1990, 91. 
words continue to resonate with perfect clarity concerning Serbian-America relations:

"It is fitting that the people of the United States, dedicated to the self-evident truth that is the right of the people of all nations, small as well as great, to live their own lives and choose their own Government, and remembering that the principles for which Serbia has so nobly fought and suffered are those for which the United States is fighting, should on the occasion of this anniversary manifest in an appropriate manner ... and to invoke the blessings of Almighty God upon them and upon the cause to which they are pledged."

Serbia suffered the worst casualties, as a proportion of its population, of all nations in World War I. Out of a population of 4 million, Serbia lost 1.1 million people in the war, or $27 \%$ of its population and over $60 \%$ of its male population. 265,000 Serbian soldiers died or $25 \%$ of all mobilized men (Pajic 2015). To understand this, is to understand Serbia's selfless sacrifice as a vital component of the victorious conclusion of the Great War.

Endeavoring to present Nicholai's providential mission on behalf of Serbia to America in 1915, together with the altruistic efforts of the eminent likes of Professor Michael I. Pupin and Mrs. Helen Losanitch-Frothingham, in light of the Centenary of President Wilson's message, leading to the breaking through of the Salonica Front, the liberation of Serbia, and the conclusion of World War I, is to revisit Serbian-American relations today, in the faithful light of Serbia and her Diaspora yesterday. 


\section{Bibliography}

\section{Sources:}

"Many Slavs Here Declare for Allies." 1915. The New York Times, Vol. LXIV, No. 21.037 (Monday, August 30, 1915): 2.

"Appeals to Americans to Pray for Serbians." 1918. The New York Times, Vol. LXVII, No. 22,099 (Saturday, July 27, 1918): 4.

"Dedicate the Flag of a New Nation." 1918. The New York Times, Vol. LXVII, No. 22,100 (Sunday, July 28, 1918): 8.

1979 Calendar of the Serbian Orthodox Church in the USA and Canada. 1979. Chicago: The Clergy Brotherhood.

Declassified State Department archival material $1-8-58$ of July $17,1962$. National Archives and Records Administration, Records of the Department of State.

\section{Literature:}

Dobrijević, Irinej. 2007. "Saint Nicholai of Zhicha: A Contemporary Orthodox Witness." Philotheos: International Journal for Philosophy and Theology, Vol. 7 (2007): 456-462. https://doi.org/10.5840/philotheos2007733. Dobrijevic, Irinej. 2018. "Nicholai Velimirovich: The Great War and America 1915-1918." In The Great War 1914-1918: The Kingdom of Serbia, The United States of America and the Serbian American Diaspora, edited by Krinka Vidakovic Petrov, 229-237. Alhambra: Sebastian Press.

Dobrijevic, Mirko (later, Bishop Irinej). 1979. "Nicholai at St. Tikhon's 19511956: The 'Forgotten' Years of His Life." BA Thesis. South Canaan, PA: St. Tikhon's Orthodox Theological Seminary.

Frothingham, Helen Losanitch. 1970. Mission for Serbia: Letters from America and Canada 1915-1920. Edited by Matilda Spence Rowland. New York: Walker and Company.

Grcic, Mirko, and Gnjato, Rajko [Грчић, Мирко Д. | Гњато, Рајко]. 2004. „О националном раду Михајла Пупина = The Role of Michael Pupin in Solving of Serbian National Question“. Гласник Срйскої їеоірафскої gрушитва = Bulletin de la Société serbe de géographie, Vol. LXXXIV, 6p. 2 (2004): 71-82. https://doi.org/10.2298/GSGD0402071G.

Heppel, Muriel. 2003. George Bell and Nicholai Velimirovich: The Story of a Friendship. Translated to Serbian by Matej Arsenijevic. Cetinje, Sve- 
tigora [= Хепел, Мјуријел. 2003. Џори Бел и Николај Велимировић: ирича о јеgном ирријаиельстиву. Са енглеског превео Матеј Арсенијевић. Библиотека „Свети Петар Цетињски“, коло „Исток-Запад“, књ. 1. Цетиње: Светигора].

Milkic, Miljan [Милкић, Миљан]. 2016. Верска служба у срйској војсци

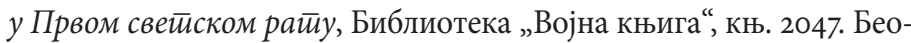
град: Медија центар „Одбрана“.

Ostojic-Fejic, Ubavka [Ostojić-Fejić, Ubavka]. 1994. Sjedinjene Američke Države i Srbija: 1914-1918. Studije i monografije / Institut za savremenu istoriju. Beograd: Institut za savremenu istoriju, 1994.

Pajic, Bojan. 2015. "Serbia in the Great War 1914-18." Melbourne, February 2, 2015 [cf. also Serbian Orthodox Church Australia and New Zealand. 2015. "Exhibition: Serbia in the Great War." Monday, August 31, 2015. https://soc.org.au/en/news/272-exhibition-serbia-in-the-great-war].

Velimirovich, Nicholai [Велимировић, Николај]. 1915. I Највиши - II Мојсеј. Жива Црква: Недељни гласник Словенског хришћанства, No. 4. New York.

Vidakovic Petrov, Krinka, ed. 2018. The Great War 1914-1918: The Kingdom of Serbia, The United States of America and the Serbian American Diaspora. Alhambra: Sebastian Press.

Vukovic, Sava, Bishop of Sumadija [Вуковић, Епископ шумадијски Сава]. 199о. „Мисија јеромонаха др Николаја Велимировића у Америци 1915“. Каленgар Црква (Београд 1990): 89-90.

West, Canon Edward N. 1979. "Recollections of Bishop Nicholai." In 1979 Calendar of the Serbian Orthodox Church in the USA and Canada. Chicago: The Clergy Brotherhood.

Zivojinovic, Dragoljub [Живојиновић, Драгољуб Р.]. 1984. „Југословенске земље у политици Сједињених Америчких Држава до 1918. године“. Зборник Майице срӣске за истиорију = Proceedings of Matica Srpska for History, Vol. 29 (1984): 49-68. 